\title{
MATERIAL AND GEOMETRICAL CHARACTERISTICS OF STRUCTURAL STEELS BASED ON STATISTICAL ANALYSIS OF METALLURGICAL PRODUCTS
}

\author{
Zdeněk Kala $^{1}$, Jindřich Melcher ${ }^{2}$, Libor Puklický ${ }^{3}$ \\ Brno University of Technology, Faculty of Civil Engineering, Institute of Structural Mechanics, \\ Veveři Str. 95, 60200 Brno, Czech Republic \\ E-mail: ${ }^{1} k a l a . z @ f c e . v u t b r . c z ;{ }^{2} m e l c h e r . j @ f c e . v u t b r . c z ;{ }^{3}$ l.puklicky@centrum.cz \\ Received 06 Apr 2009; accepted 12 June 2009
}

\begin{abstract}
The experimental research results of material and geometrical characteristics of Czech steel are given in the presented paper. Measurements are carried out for the yield strength of plates made of steel grade S355. The values measured are used to compute axial resistances which are compared with the resistance resulting from standard (nominal) values. In this paper, there was used a statistical information for evaluating the results of strength measurements on a series of plates and hot-rolled profiles under tension to determine the adequate partial $\gamma_{\mathrm{M} 0}$ safety factor.
\end{abstract}

Keywords: material, steel, yield strength, reliability, structure, design, random.

\section{Introduction}

Steel structures have a long tradition and great history in Czech Republic. Žd'ákovský bridge over the Vltava from the 1960's belongs to the largest arched bridges in the world. Former Czechoslovakia was from the Second World War till the end of the $20^{\text {th }}$ century one of the world's largest producers of iron and steel in terms of production per inhabitant. This was due to political reasons. Change in political situation, subsequent fall of Czechoslovakia and the creation of Czech Republic was accompanied by decrease in steel production. At present, production of steel lays predominantly in the hands of foreign owners and management. $700 \mathrm{~kg}$ of steel per inhabitant is produced yearly in the Czech Republic. This is approximately double the number in other developed European countries. There is a large competition between producers. The decisive criterion for foreign management is price, leading to the shift of production volume to countries with lower production costs and more tolerant ecological regulations. Due to this and other reasons we can objectively expect that a decrease of production in Czech smelting plants will continue.

The development of the economic situation initiated and initiates a number of non-commercially aimed research projects aimed at the long time monitoring of the change in quality of metallurgical products, not only in central Europe. These researches provide detailed statistical information on the material and geometric characteristics of steel products and are important in terms of the verification of the indicators of reliability of the EUROCODE standards. Non-commercially aimed researches are not identical with activities performed by producers, which are aimed more at the adherence of standard production procedures and optimization of economical aspects.

Traditionally, the material yield strength, tensile strength and ductility have been studied among the mechanical characteristics of structure steels. For dimensioning the structures, yield strength is the most important above all. 95\% of valid observations of yield strength should be higher than the nominal value of yield strength listed in EUROCODE 3. If this is not met, it is necessary to recommend product quality improvements. Reliable conclusions require a high number of valid observations.

Extensive research of material characteristics of Czechoslovakian steel in the 1960's and 1970's (Mrázik, Sadovský 1992) produced valuable information on the quality and reliability of steel structures. One of the first comprehensive papers (Rozlívka et al.) publishing the most important material characteristics of steel products of a dominant Czech manufacturer subsequently became the source of input data for a number of reliability studies using the Monte Carlo method, whose popularity interrelated with the quick development of potential of computers. The most important results of experimental research are yield strength, tensile strength, ductility of steel plates and flanges of cross-sections IPE and geometrical characteristics of cross-sections IPE from 1989 till 2004 are published (Melcher et al. 2004). With regard to international cooperation we can in this period accentuate mainly the comparison of the above-listed material characteristics of the dominant Czech and Austrian producers (Kala et al. 2005; Strauss et al. 2006). In an independent manner, material characteristics of steel products of both Austrian and Czech makers were statistically evaluated at the Vienna and the Brno Universities with the aim of guaranteeing the maximum objectivity of the results obtained and of the conclusions drawn by them (Kala et al. 
2004; Strauss et al. 2006). It is also necessary to mention of the extensive experimental research performed in Hungary (Szalai, Papp 2009).

Attention is paid lately in the Czech Republic to the research of material characteristics of highly utilized structures of steel S355 (Melcher et al. 2008). The aim of the paper is to provide new information on the listed characteristics from the year 2007. The studies published here link up with the long-term non-commercial experimental research, the results of which were published in (Mrázik, Sadovský 1992; Rozlívka et al.; Melcher et al. 2004; Kala et al. 2005; Strauss et al. 2006; Szalai, Papp 2009; Melcher et al. 2008).

\section{Material characteristics of steel S355 plates}

The yield strength is the fundamental parameter representing the basis for derivation of design characteristics and partial safety factors of steels. The mutual difference of yield strength values of plates in dependence on their thickness was studied in the course of experimental research.

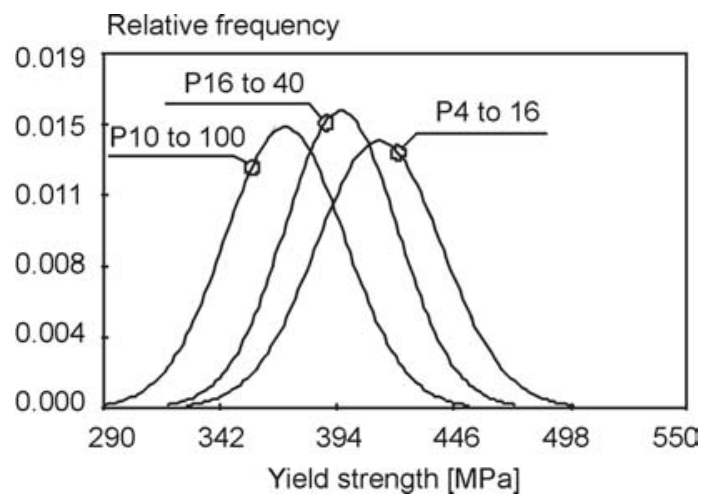

Fig. 1. Gauss density functions of yield strength

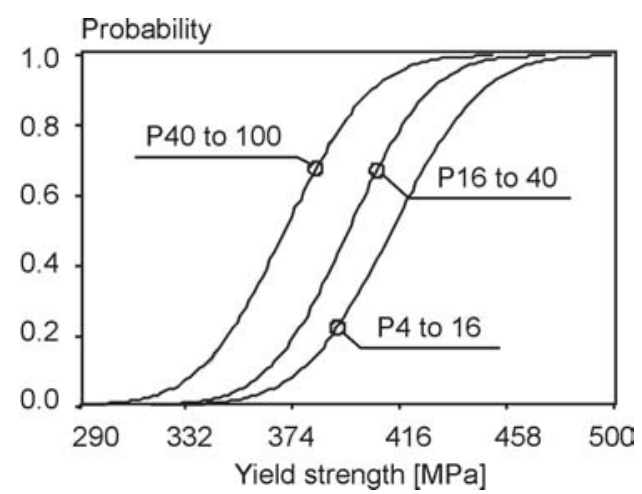

Fig. 2. Gauss probability model of yield strength

We obtained 2138 samples of P4-16, 1368 samples of P16-40, and 689 samples of P40-100. The approximations of the measured data of Gauss density probability functions are depicted in Fig. 1 and Fig. 2. The comparisons of the Hermite and the Gauss density probability functions are to be seen in Fig. 3 to Fig. 5 .

The Hermite density probability function is a fourparametric function (accessible, e.g., in the computer programme Statrel, version 3.10), which takes into con- sideration both skewness and kurtosis of quantities measured. The largest difference between the Gauss and the Hermite density probability functions has been found for the plates with thicknesses of 4 to $40 \mathrm{~mm}$ (Fig. 3.) This difference is caused by a relatively high value of kurtosis, 5.3305. The survey of the yield strength statistical characteristics is given in Table 1 .

Table 1. Statistical analysis of yield strength

\begin{tabular}{ccccc}
\hline Thickness & $\begin{array}{c}\text { Mean } \\
\text { value }\end{array}$ & $\begin{array}{c}\text { Standard } \\
\text { deviation }\end{array}$ & Skewness & Kurtosis \\
\hline $4-16 \mathrm{~mm}$ & 412.68 & 27.941 & 0.947 & 5.330 \\
$16-40 \mathrm{~mm}$ & 395.68 & 25.126 & 0.036 & 2.870 \\
$40-100 \mathrm{~mm}$ & 370.72 & 26.568 & 0.126 & 3.150 \\
Unit & $\mathrm{MPa}$ & $\mathrm{MPa}$ & - & - \\
\hline
\end{tabular}

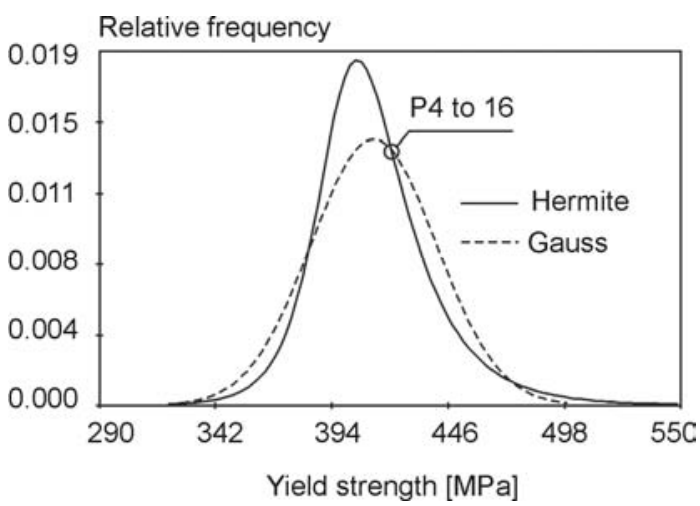

Fig. 3. Gauss vs. Hermite distribution functions

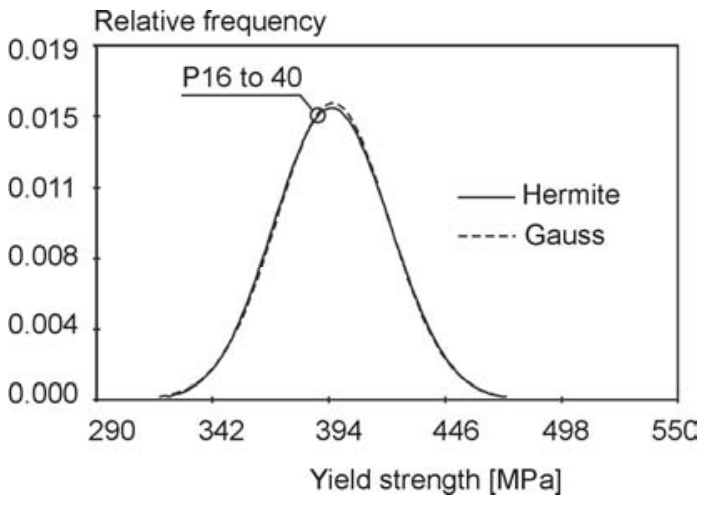

Fig. 4. Gauss vs. Hermite distribution functions

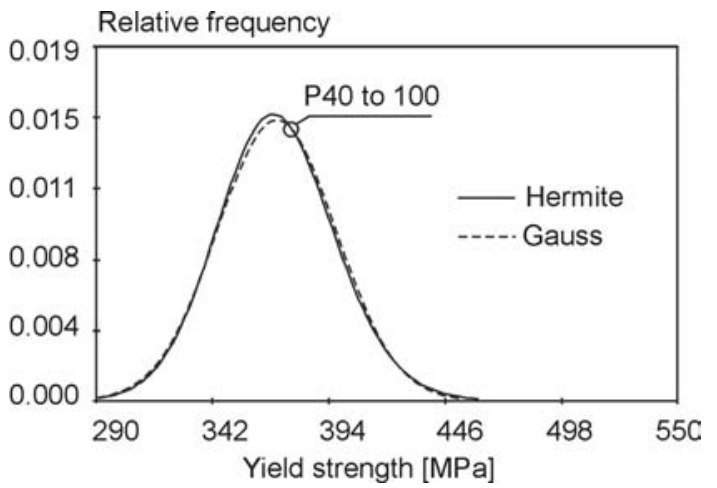

Fig. 5. Gauss vs. Hermite distribution functions 


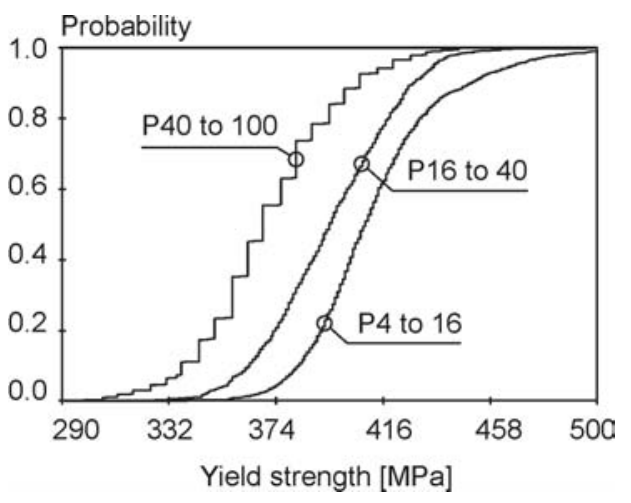

Fig. 6. Real probability model of yield strength

The real probability model of yield strength was obtained from measured data (Fig. 6). As the manufacturing process is concerned, the frequency of the occurrence of yield strength being lower than the nominal value is controlled as a parameter characterizing the production quality. The yield strength nominal value for plates with thickness lower than $40 \mathrm{~mm}$ is $355 \mathrm{MPa}$, for plates with thickness higher than $40 \mathrm{~mm}$, it is $335 \mathrm{MPa}$, see Standard EUROCODE 3. If the manufacturing quality is convenient, the number of values lower than the nominal value must be less than $5 \%$.

In effect, it is compared, whether the $5 \%$ quantile (characteristic value) is higher than the nominal value. To assess this quantile with a reliability, it would be necessary to have a large number of measured values at the disposal. If the number of measured samples is rather low, one of the ways how to obtain an assessment of the characteristic value is the approximation of the set containing the data measured by an appropriate type of the probability density distribution function.

The characteristic values obtained from some most frequently used probability density distribution functions are presented in Table 2.

Table 2. Characteristic values of yield strength

\begin{tabular}{ccccc}
\hline Thickness & Gauss & Lognormal & $\begin{array}{c}\text { Shift } \\
\text { lognorm }\end{array}$ & $\begin{array}{c}\text { Nominal } \\
\text { value }\end{array}$ \\
\hline $4-16 \mathrm{~mm}$ & 366.72 & 368.39 & 374.75 & 355 \\
$16-40 \mathrm{~mm}$ & 354.35 & 355.76 & 354.62 & 355 \\
$40-100 \mathrm{~mm}$ & 327.02 & 328.70 & 328.00 & 335 \\
Unit & $\mathrm{MPa}$ & $\mathrm{MPa}$ & $\mathrm{MPa}$ & $\mathrm{MPa}$ \\
\hline
\end{tabular}

It is evident from Table 2 that the characteristic values for plates with thickness of 4-16 $\mathrm{mm}$ are higher than the nominal value in all cases. The characteristic values of plates with thickness of $16-40 \mathrm{~mm}$ are approximately equal to the nominal value (small differences are insignificant from the technology point of view). In all cases, the characteristic values of plates with thickness of 40 $100 \mathrm{~mm}$ are lower than the nominal value.

\section{Design values of yield strength and partial safety factors}

The design value of material resistance is determined as the product of random variables (Melcher et al. 2008):

$$
R=f \cdot \varphi_{\mathrm{A}} \cdot \varphi_{0},
$$

where $f$ is yield strength; $\varphi_{\mathrm{A}}-$ non-dimensional random area (cross-section area divided by nominal value: $A / A_{\mathrm{n}}$ ); $\varphi_{0}$ deviation of theoretical model from the results of tests.

When calculating the material strength on the basis of yield strength random values, $\varphi_{0}=1.0$ is usually considered (Melcher et al. 2008). For plates, the mean value 1.0 and the standard deviation 0.03 are usually assumed for $\varphi_{\mathrm{A}}$. For the hot-rolled profiles non-presented here, the standard deviation for $\varphi_{\mathrm{A}}$ can be considered to be 0.02 (Melcher et al. 2008; JCSS ... 2001).

For calculating design values $R(1), 400000$ simulation runs of the Monte Carlo method were used. It has been supposed that the yield strength has the Gauss, lognormal, shift lognormal probability density functions (Tables 3 and 4) and that the coefficient $\varphi_{\mathrm{A}}$ has the Gauss probability density distribution function, and that $\varphi_{0}=$ 1.0. In compliance with the articles of (JCSS ... 2001; EN $1990 \ldots$ 2003), the design value $R_{\mathrm{d}}$ was evaluated from the basic probability definition as the $0.1 \%$ quantile (Melcher et al. 2004).

Table 3. Design values $R_{\mathrm{d}}$ of yield strength

\begin{tabular}{ccccc}
\hline Thickness & Gauss & Lognormal & $\begin{array}{c}\text { Shift } \\
\text { lognorm }\end{array}$ & $\begin{array}{c}\text { Design } \\
\text { value }\end{array}$ \\
\hline $4-16 \mathrm{~mm}$ & 320.5 & 330.3 & 343.4 & 355 \\
$16-40 \mathrm{~mm}$ & 312.2 & 320.5 & 312.7 & 355 \\
$40-100 \mathrm{~mm}$ & 283.9 & 293.3 & 287.8 & 335 \\
Unit & $\mathrm{MPa}$ & $\mathrm{MPa}$ & $\mathrm{MPa}$ & $\mathrm{MPa}$ \\
\hline
\end{tabular}

Let us introduce a clear procedure of partial safety factor $\gamma_{M}$ verification, e.g. for plates with thickness $4-$ $16 \mathrm{~mm}$. The computer algorithm of calculation $\gamma_{M}$ can be described in the following way:

-400000 runs of the yield strength $f$ are generated by application of the Monte Carlo method. Statistical characteristics are given in Table 1. As the number of measurements is relatively low and does not enable us to determine the density distribution function of yield strength accurately, this function must be selected (e.g. Gauss).

- By application of the Monte Carlo method, 400000 runs of $\varphi_{\mathrm{A}}$ are generated; it is the coefficient having the Gauss density distribution function with mean value 1.0 and the standard deviation 0.03 . The $\varphi_{0}$ is deterministic value of 1.0 .

- According to the relation (1), 400000 runs of material resistance $R=f \cdot \varphi_{\mathrm{A}}$ are calculated. 400000 runs of $R$ are rank-ordered from the lowest value to the highest one. The lowest realization of $R$ is the first value, the highest, the last one. The design value $R_{\mathrm{d}}$, calculated as 0.1 percent quantile, is the 400th value in the ordered set.

- Partial safety factor $\gamma_{M}$ is calculated from the relation

$$
\gamma_{M}=\frac{355 \cdot 10^{6}}{R_{d}},
$$

where $355 \cdot 10^{6} \mathrm{~Pa}$ is nominal value of yield strength for thickness 4-16 $\mathrm{mm}$ (for thickness $40-100 \mathrm{~mm}$, this value is $\left.335 \cdot 10^{6} \mathrm{~Pa}\right)$. 
The results of partial safety factor $\gamma_{M}$ are in Table 4 .

Table 4. Partial safety factors $\gamma_{M}$

\begin{tabular}{ccccc}
\hline Thickness & Gauss & Lognormal & $\begin{array}{c}\text { Shift } \\
\text { lognorm }\end{array}$ & EC 3 \\
\hline $4-16 \mathrm{~mm}$ & 1.11 & 1.07 & 1.03 & 1.0 \\
$16-40 \mathrm{~mm}$ & 1.14 & 1.11 & 1.14 & 1.0 \\
$40-100 \mathrm{~mm}$ & 1.18 & 1.14 & 1.16 & 1.0 \\
\hline
\end{tabular}

Partial safety factors $\gamma_{M}$ in Table 4 are given in dependence on the density distribution function of yield strength. The number of yield strength observations is relatively high; nevertheless, more observations are needed to get a satisfactorily accurate statistic analysis of $R_{d}$ and/or $\gamma_{\mathrm{M}}$. A statistically acceptable mistake would be obtained only after more than 100000 observations; however, it is very expensive from the economic and organisation points of view. The values $\gamma_{M}$ are therefore sensitive to the epistemic uncertainty (Kala 2007b, 2008a, $2008 \mathrm{~b}$ ), nevertheless, they provide basic information on intervals within which $\gamma_{M}$ lies with high probability. The sensitivity of the type of density function manifested itself, to maximum degree, for thickness $4-16 \mathrm{~mm}$ (Table 4), where a relatively high kurtosis 5.33 (Table 1) was found for yield strength. For the other thicknesses, relatively low skewness and kurtosis values were found (Table 1), and therefore it can be inclined to the results obtained on behalf of the Gauss density functions (Table 4).

The results from Table 1 to Table 4 cannot be generalized for yield strength of hot-rolled profiles. In the case of yield strength of hot-rolled profiles, it is therefore required to know the yield stress distribution along the cross-section in more detail (see e.g. Kala, Z., Kala, J. 2002). The only right way to obtain information on yield strength variability in a hot-rolled profile is to carry out material tests by taking the samples from different profile points. A suitable auto-correlation function and correlation length of a random field could be recommended as the output, see e.g. (Kala 2003).

\section{Geometric characteristics of hot-rolled profiles}

Observance of geometric dimensions and weight of bars are pre-eminently checked in production. Tolerances on geometrical shape and dimensions are listed in the Tolerance Standard EN 10034:1993, see Figs 7-9. The permitted limit deviation of the actual weight from the theoretical weight is given as $\pm 4 \%$ for individual bars. The variables $h, b_{1}, b_{2}, t_{1}, t_{21}, t_{22}$, see Figs 7-8, were statistically evaluated by experimentally obtained data.

We obtained 369 valid observations. The measured valid observations $h, b_{1}, b_{2}, t_{1}, t_{21}, t_{22}$ are depicted in Figs 10-15. Relative geometrical characteristics were evaluated. The relative geometrical characteristic is given as the ratio of the real characteristic obtained from the measurement of cross-sectional geometry (e.g. crosssection depth $h$ ) to the nominal dimension of the crosssectional one (Melcher et al. 2004).

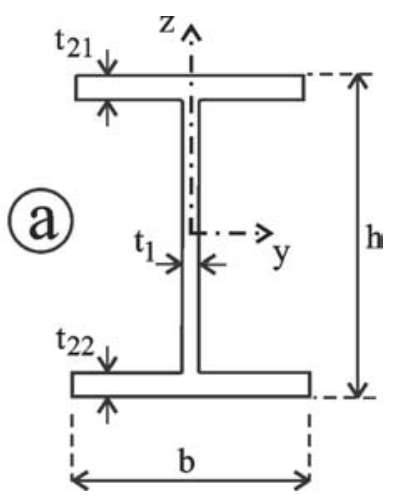

Fig. 7. Geometric characteristics $h, b, t_{1}, t_{21}, t_{22}$

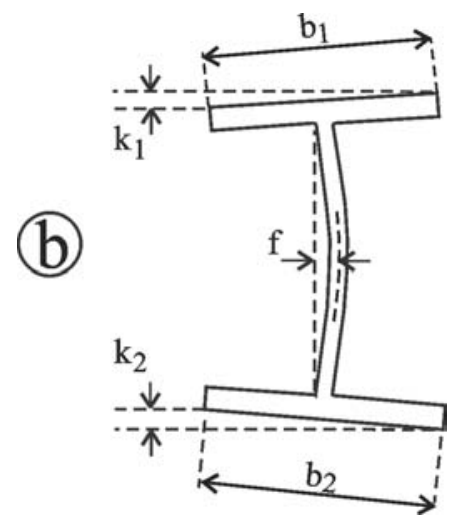

Fig. 8. Geometric characteristics $b_{1}, b_{2}, f, k_{1}, k_{2}$

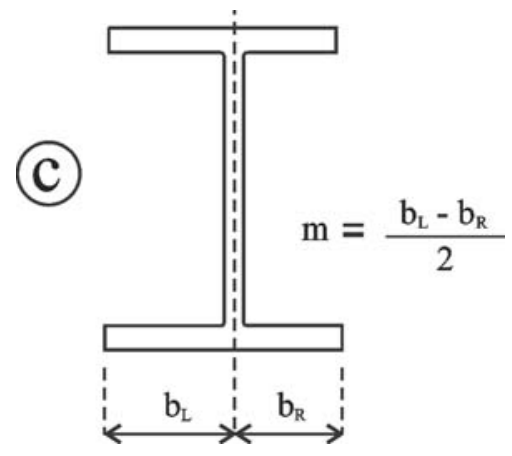

Fig. 9. Geometric characteristics $b_{\mathrm{L}}, b_{\mathrm{R}}$

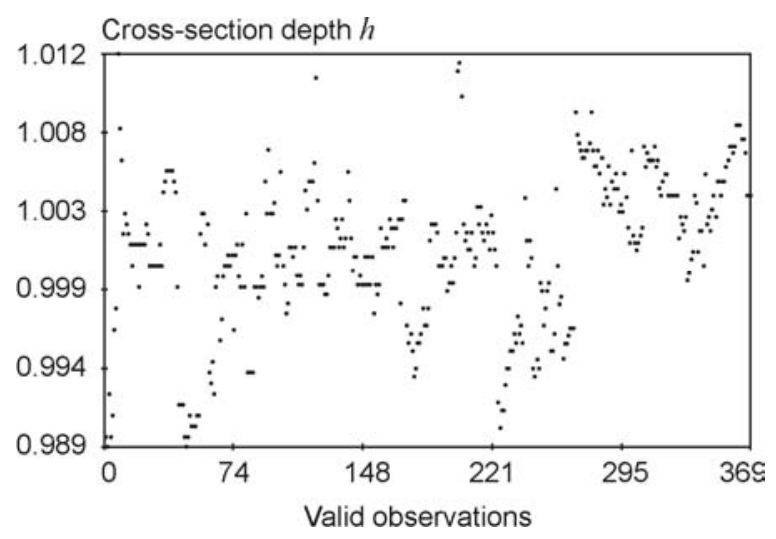

Fig. 10. Measurement of cross-section depth $h$ 


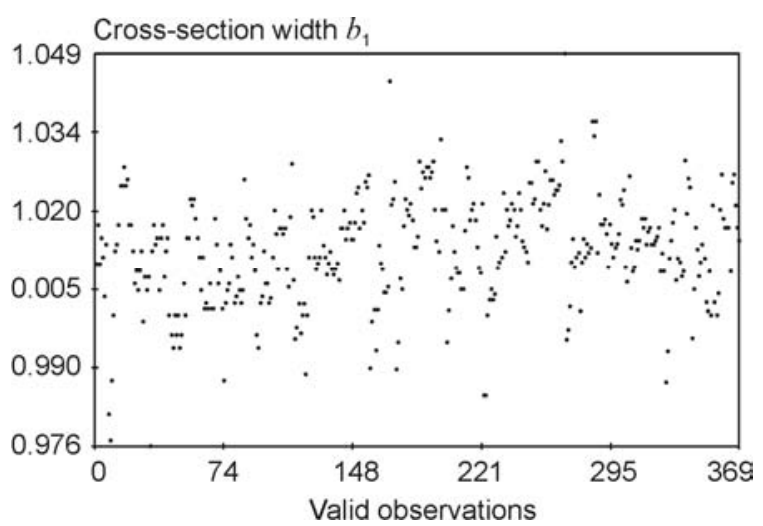

Fig. 11. Measurement of cross-section width $b_{1}$

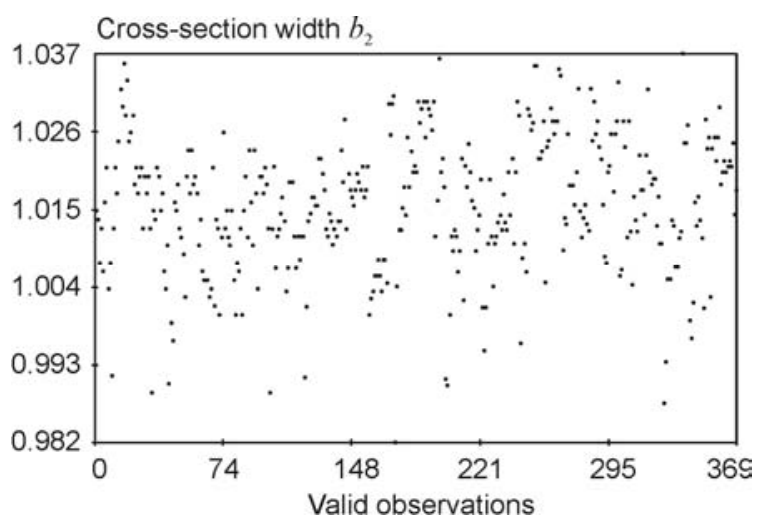

Fig. 12. Measurement of cross-section width $b_{2}$

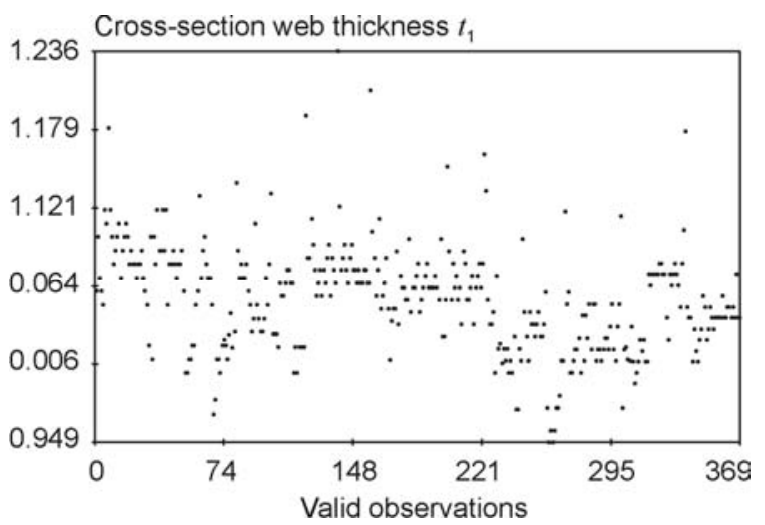

Fig. 13. Measurement of web thickness $t_{1}$

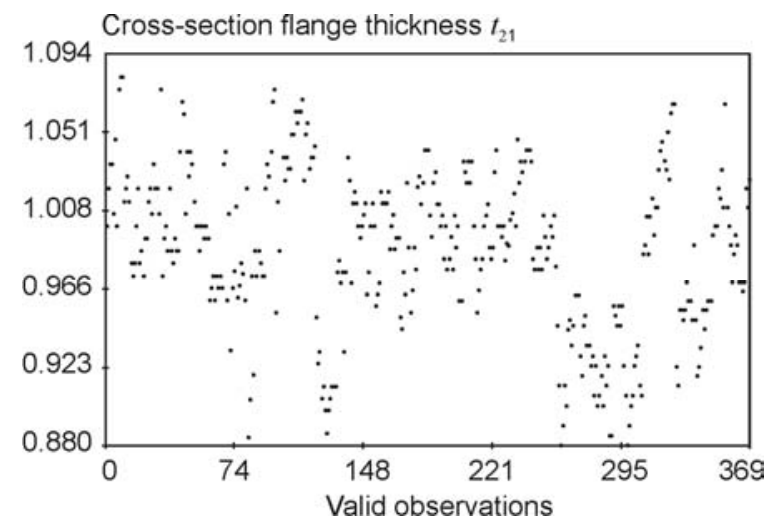

Fig. 14. Measurement of flange thickness $t_{21}$

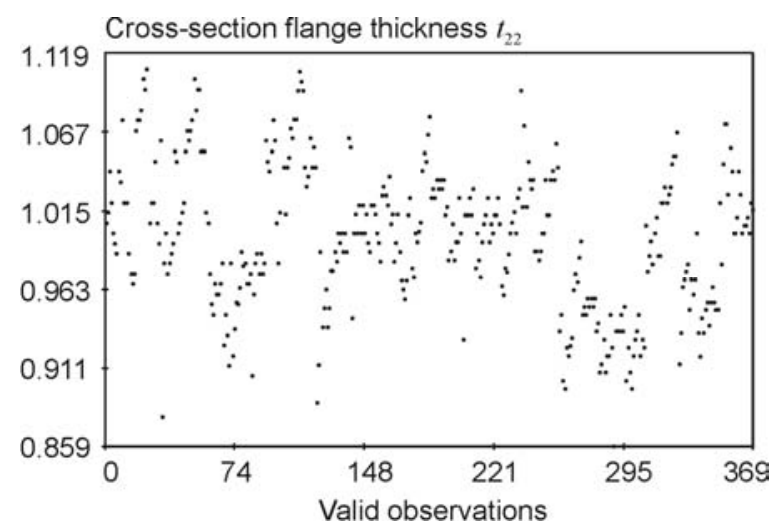

Fig. 15. Measurement of flange thickness $t_{22}$

The relative (non-dimensional) statistical characteristics are listed in Table 5. The results of sensitivity analyses (Kala 2004, 2005, 2007a, 2008c, 2009) clearly illustrate that the flange thickness is, for ultimate limit state, the dominant variables of cross-section. The results (Kala 2009; Szalai 2003) show the typical shapes of the sensitivity diagrams as the function of the slenderness.

Table 5. Statistical analysis of geometrical characteristics

\begin{tabular}{lcccc}
\hline \multicolumn{1}{c}{ Thickness } & $\begin{array}{c}\text { Mean } \\
\text { value }\end{array}$ & $\begin{array}{c}\text { Standard } \\
\text { deviation }\end{array}$ & Skewness & Kurtosis \\
\hline Section depth $h$ & 1.0009 & 0.0044233 & -0.4088 & 3.0305 \\
Section width $b_{1}$ & 1.0124 & 0.010103 & -0.3042 & 4.0460 \\
Section width $b_{2}$ & 1.0154 & 0.0093995 & -0.4069 & 3.3635 \\
Web thick. $t_{1}$ & 1.0540 & 0.039053 & 0.5306 & 4.9671 \\
Flange thick. $t_{21}$ & 0.9878 & 0.043528 & -0.3029 & 2.6657 \\
Flange thick. $t_{22}$ & 0.9977 & 0.047625 & -0.0059 & 2.7161 \\
\hline
\end{tabular}

The flanges are rolled approximately evenly within the positive and negative tolerances (mean value and median are close to one).

For the two-axially symmetrical cross-section, statistical characteristics of quantities $t_{21}$ and $t_{22}$ should be approximately identical, when supposing the high number of samples measured. Small differences between statistical characteristics of the quantities mentioned observed in Table 6 are probably due to a relatively low number of measurements. As it will be shown further on, there exists a strong correlation between $t_{21}$ and $t_{22}$. The use of couples of random quantities $t_{21}, t_{22}$ and $b_{1}, b_{2}$ in reliability calculations is singular. In reliability studies, statistical characteristics of the symmetric cross-section are frequently applied, see, e.g., (Kala 2004, 2005, 2007a, b, 2008a, b, c, 2009; Szalai 2003). In practice, it means that (i) section widths $b_{1}$ and $b_{2}$ are evaluated as one random quantity $b$ and (ii) flange thicknesses $t_{21}$ and $t_{22}$ are evaluated as one random quantity $t_{2}$. The statistical characteristics of the quantity $b$ given in Table 6 were evaluated, based on 738 valid observations; the same procedure was applied to flange thicknesses $t_{2}$.

The histograms of non-dimensional section width $b$ and non-dimensional flange thickness $t_{2}$ are depicted in Figs 16, 17. 
Table 6. Statistical analysis of geometrical characteristics

\begin{tabular}{ccccc}
\hline Thickness & $\begin{array}{c}\text { Mean } \\
\text { value }\end{array}$ & $\begin{array}{c}\text { Standard } \\
\text { deviation }\end{array}$ & Skewness & Kurtosis \\
\hline Section width $b$ & 1.0139 & 0.009868 & -0.3711 & 3.7302 \\
Flange thick. $t_{2}$ & 0.9927 & 0.045859 & -0.1039 & 2.7782 \\
\hline
\end{tabular}

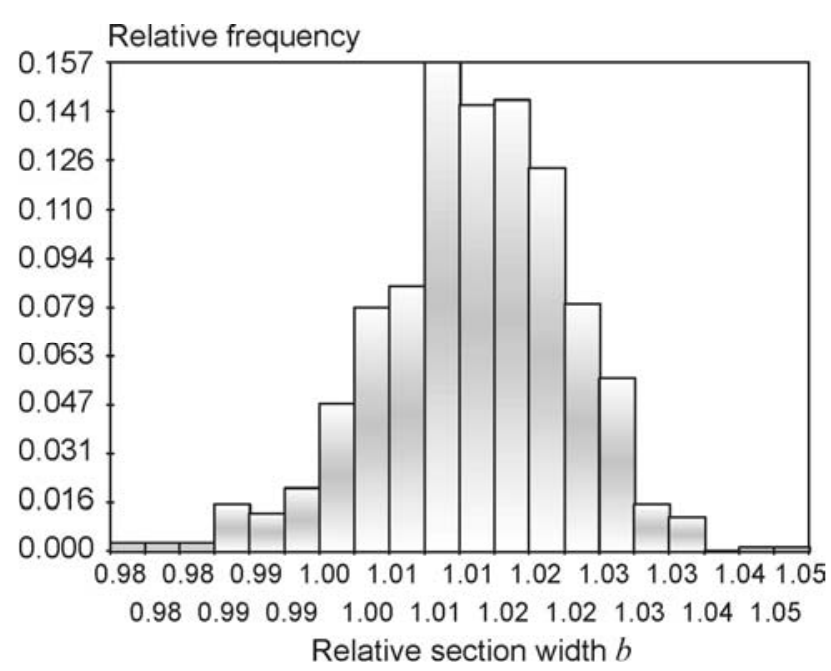

Fig. 16. Histogram of cross-section width $b$

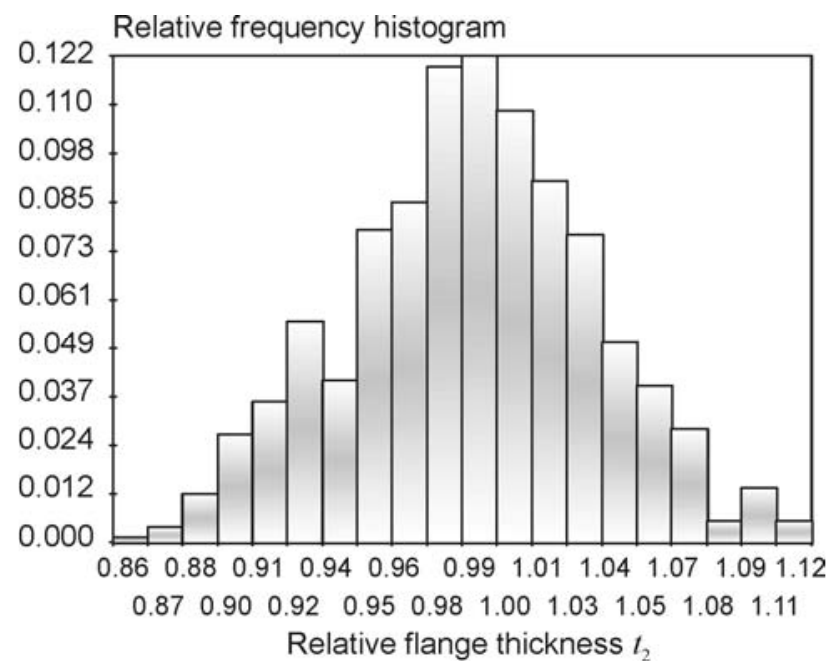

Fig. 17. Histogram of flange thickness $t_{2}$

The correlation matrix (2) was evaluated, based on a relatively low number of measurements (369), which will have to be completed, and the results evaluated to be specified in future.

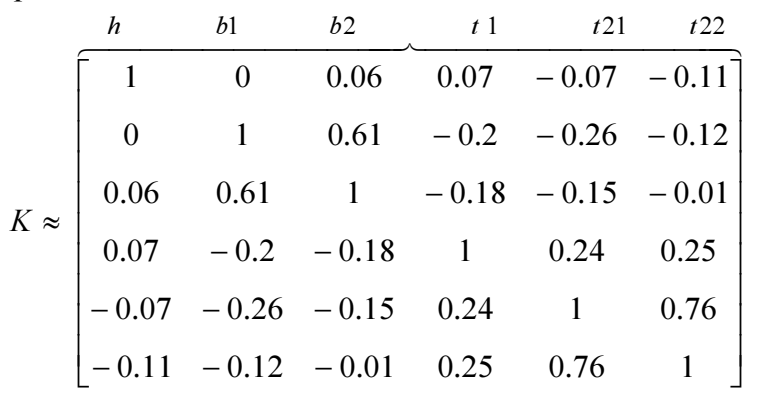

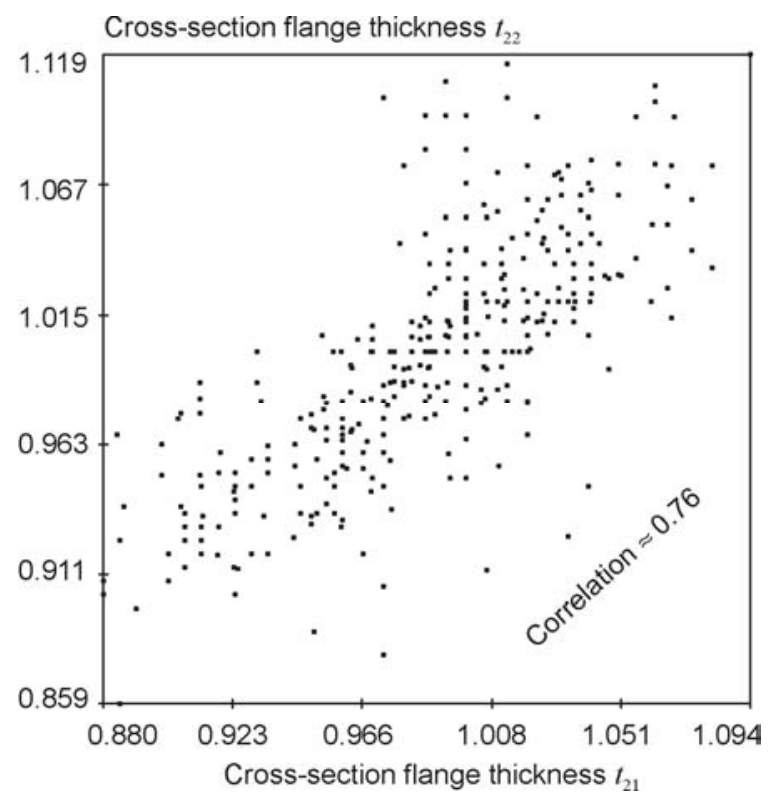

Fig. 18. Flange thickness $t_{21}$ vs. $t_{22}$

It is evident from correlation matrix (2) that a certain positive strong correlations exist between $t_{21}$ and $t_{22}$ and between $b_{1}$ and $b_{2}$. The most significant dependences between two factors (correlations) are depicted in Figs 18-21.

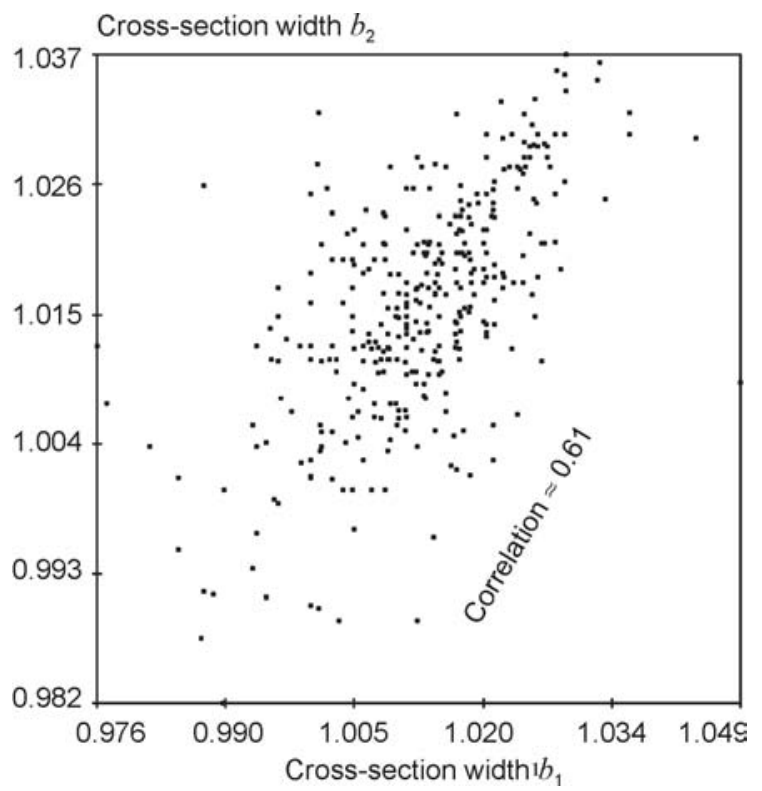

Fig. 19. Cross-section width $b_{1}$ vs. $b_{2}$

Geometrical characteristics $k_{1}, k_{2}, f, m$ were not measured. The variability of geometric characteristics $k_{1}$, $k_{2}, f, m$ has a relatively small influence on the ultimate limit states and can be considered as deterministic. 


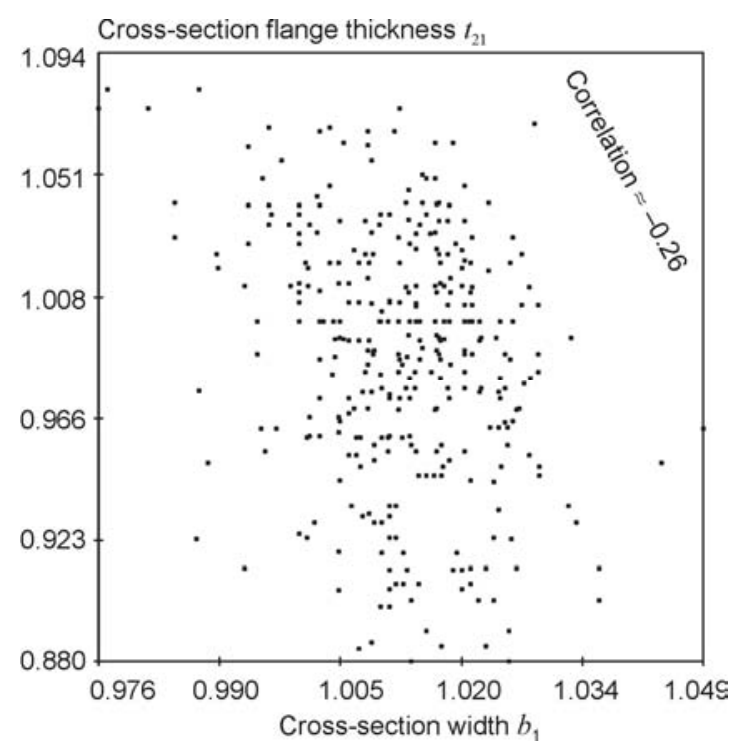

Fig. 20. Cross-section width $b_{1}$ vs. thickness $t_{21}$

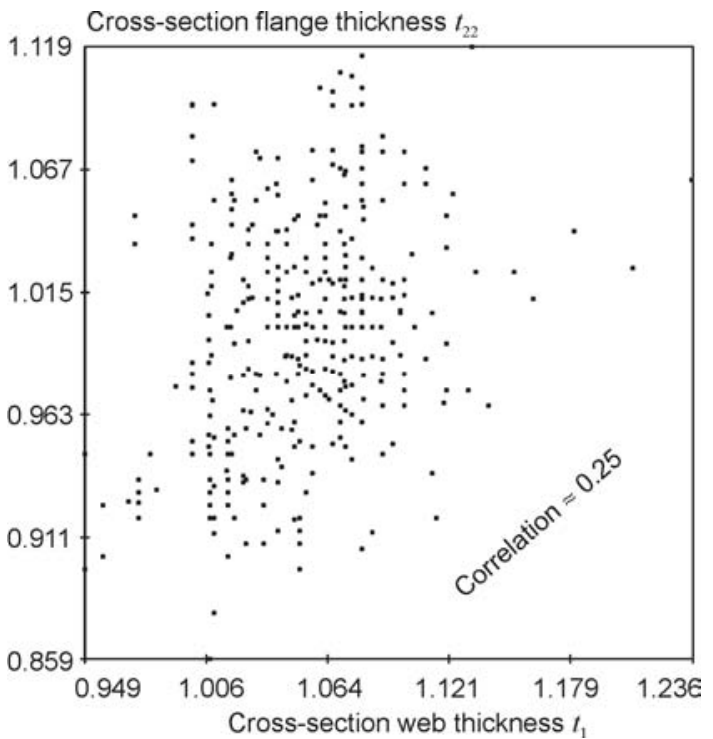

Fig. 21. Web thickness $t_{1}$ vs. flange thickness $t_{22}$

\section{Reliability of steel structures}

The results of statistical analysis represent important input data for reliability studies, techniques and optimisation problems in contemporary computational mechanics; see e.g. (Frangopol et al. 2008; Jatulis et al. 2007; Juozapaitis et al. 2006, 2008a, b; Juozapaitis, Norkus 2007; Karkauskas, Norkus 2001, 2006; Kaklauskas et al. 2008; Mang et al. 2009a, b; Mang 2009; Strauss et al. 2008). With the aim to improve the reliability of load-bearing structures, it is necessary to work towards both to the improvement of processes to prove the reliability, and for development of quality in manufacturing the steel structures.

For the purpose of aiming at these objectives, the probabilistic assessment can be also enlarged by the sensitivity analysis, (see e.g. Kala 2004, 2005, 2007a, 2008c, 2009, Szalai 2003) and (Mang et al. 2009). New results of sensitivity analysis of systems illustrate that the interaction effects between input imperfections can have a significant influence (Kala 2008c). The sensitivity analysis identifies these quantities with a dominant effect on reliability, which should be controlled with intensified accuracy during the manufacturing process (Kala 2008c). Moreover, the sensitivity analysis also supplies important background for formulation, verification, and calibration of the reliability indices of Standards for designing, and for parameters of Tolerance Standards.

\section{Conclusion}

It can be observed from the results of experimental yield strength measurements of plates divided into three categories of thicknesses that, for plates of higher thickness, the yield strength mean value is lower. The difference between the yield strength mean value of plates with thickness of 4-16 mm and of those with thickness of 40$100 \mathrm{~mm}$ is approximately $10 \%$. The differences occur, as well, between standard deviation values, but it is necessary to take into consideration the statistical error due to small number of measurements. The reliability of steel structures is also influenced by the yield strength skewness and kurtosis. The profiles U65 to U140 of steel grade S355 show, in comparison with the plates, a lower standard deviation (see Melcher 2004, 2008). These conclusions have been confirmed by a long-term study of material characteristics (Mrázik, Sadovský 1992; Rozlívka et al.; Melcher et al. 2004; Kala et al. 2005; Strauss et al. 2006; Szalai, Papp 2009; Melcher et al. 2008).

The mean value of non-dimensional geometrical characteristics $h, b_{1}, b_{2}, t_{1}$ was higher than one, the mean value of geometrical characteristics $t_{21}, t_{22}$ approaches to one very closely. It means that average values of these characteristics approach the nominal values given by the manufacturer. Higher statistical characteristics, the standard deviation in particular, are also important for the reliability of structures. From the perspective of dimension tolerance, namely thickness, there exists the tendency to roll within the negative part of the tolerance limit. Improving technical possibilities enables that the deviation limits provided by standards are not used. In the future, it is necessary to continue monitoring of these characteristics with the aim of the analysis of their influence on the reliability of newly designed structures. It is possible to find only by means of the probabilistic reliability analysis, whether the structure design is reliable or is not, see e.g. (Kala 2003).

When formulating the conclusions, also the specialist's point of view and the long-term experience are of great importance. It is necessary both to continue studying the material and geometrical characteristics of industrially manufactured structures and to aim at international cooperation of specialists concerned.

The authors gratefully acknowledge the partial support provided by (i) the Czech Science Foundation within the projects of GACR No. 103/07/1067 and (ii) the Czech Ministry of Education, Youth and Sports within the Research Project MSM0021630519. We are grateful to $C$. Eng. Miroslav Fajkus and Dr. Lubomír Rozlivka for furnishing with the data on material characteristics. 


\section{References}

EN 1990 Eurocode: Basis of Structural Design, 2003.

Frangopol, D. M.; Strauss, A.; Kim, S. 2008. Use of monitoring extreme data for the performance prediction of structures: general approach, Engineering Structures 30(12, December): $3644-3653$.

Jatulis, D.; Kamaitis, A.; Juozapaitis, A. 2007. Static behaviour analysis of masts with combined guys, Journal of Civil Engineering and Management 13(3): 177-182. ISSN 1392-3730.

JCSS Probabilistic Model Code, Part 3, Resistance Models, Static Properties of Structural Steel (Rolled Sections), JCSS Zurich, 2001. Available from Internet: <http://www. jcss.ethz.ch/>.

Juozapaitis, A.; Vainiunas, P.; Kaklauskas, G. 2006. A new steel structural system of a suspension pedestrian bridge, Journal of Constructional Steel Research 62(12, December): $1257-1263$.

Juozapaitis, A.; Norkus, A. 2007. Determination of rational parameters for the advanced structure of a pedestrian suspension steel bridge, The Baltic Journal of Road and Bridge Engineering 2(4): 173-181.

Juozapaitis, A.; Norkus, A.; Vainiūnas, P. 2008a. Shape stabilization of steel suspension bridge, The Baltic Journal of Road and Bridge Engineering 3(3): 137-144. doi:10.3846/1822-427X.2008.3.137-144

Juozapaitis, A.; Kutas, R.; Jatulis. D. 2008b. Mast behaviour analysis and peculiarities of numerical modelling, Journal of Civil Engineering and Management 14(1): 61-66.

Kaklauskas, G.; Gribniak, V; Bacinskas, D.; Vainiunas, P. 2008. Shrinkage influence on tension stiffening in concrete members, Engineering Structures 31(6): 1305-1312. doi:10.1016/j.engstruct.2008.10.007

Kala, Z. 2003. Verification of the partial reliability factors in a case of a frame with respecting random imperfections, int. colloquium, in Proc. of Int. Conference on Metal Structures, Miskolc (Hungary), 19-22, 3-5. April 2003, Millpress Science Publishers, Rotterdam.

Kala, Z. 2004. Sensitivity of load-carrying capacity of a thinwalled steel member to the initial curvature shape of its axis, in Proc. of Fourth Int. Conf. on Thin-Walled Structures, Loughborough (England, UK), 2004, 835-842.

Kala, Z. 2005. Sensitivity Analysis of the Stability Problems of Thin-Walled Structures, Journal of Constructional Steel Research 61(3, March): 415-422.

doi:10.1016/j.jcsr.2004.08.005

Kala, Z. 2007a. Sensitivity study of steel imperfect member under compression, in Proc. of 9th Int. Conf. on Modern Building Materials, Structures and Techniques, May 1618, 2007. Vilnius: Technika, 2008, Vols 1-3: 943-948.

Kala, Z. 2007b. Stability problems of steel structures in the presence of stochastic and fuzzy uncertainty, Journal of Thin-Walled Structures 45/(10-11): 861-865.

Kala, Z. 2008a. Fuzzy analysis of the failure probability of steel member under bending, in Proc. of 9th Int. Conf. on Modern Building Materials, Structures and Techniques, May 16-18, 2007, Vilnius: Technika, 2008, Vols 1-3, 937-942.

Kala, Z. 2008b. Fuzzy probability analysis of the fatigue resistance of steel structural members under bending, Journal of Civil Engineering and Management 14(1): 67-72. ISSN 1392-3730.

Kala, Z. 2008c. Sensitivity analysis of carrying capacity of steel plane frames to imperfections, in Proc. of Int. Conf. of
Numerical Analysis and Applied Mathematics, Psalidi (Greece), 2008, 298-301. ISBN 978-0-7354-0576-9, ISSN 0094-243X.

Kala, Z. 2009. Sensitivity assessment of steel members under compression, Engineering Structures 31(6): 1344-1348. doi:10.1016/j.engstruct.2008.04.001

Kala, Z.; Kala, J. 2002. Respecting the influence of geometrical and material imperfections of steel beam when calculating their load-carrying capacity, in Proc. of Int. Colloquium Stability and Ductility of Steel Structures, Budapest, 104110. ISBN 9630579502.

Kala, Z.; Strauss, A.; Melcher, J.; Novák, D.; Fajkus, M.; Rozlívka, L. 2005. Comparison of material characteristics of Austrian and Czech structural steels, International Journal of Materials \& Structural Reliability 3(1): 43-51.

Karkauskas, R.; Norkus, A. 2001. Optimization of geometrically non-linear elastic-plastic structures under stiffness constraints, Mechanics Research Communications 28(5): 505-512. doi:10.1016/S0093-6413(01)00202-6

Karkauskas, R.; Norkus, A. 2006. Truss optimization under stiffness, stability constraints and random loading, $\mathrm{Me}$ chanics Research Communications 33(2): 177-189. doi:10.1016/j.mechrescom.2005.06.002

Mang, H. A. 2009. On contemporary computational mechanics, Journal of Civil Engineering and Management 15(1): 113-128. doi:10.3846/1392-3730.2009.15.113-128

Mang, H. A.; Jia, X.; Hoefinger, G. 2009a. Hilltop buckling as the alfa and omega in sensitivity analysis of the initial postbuckling behaviour of elastic structures, Journal of Civil Engineering and Management 15(1): 35-46. doi:10.3846/1392-3730.2009.15.35-46

Mang, H. A.; Eberhardsteiner, J.; Hellmich, C.; Hofstetter, K.; Jäger, A.; Lackner, R.; Meinhard, K.; Müllner, H. W.; Pichler, B.; Pichler, C.; Reihsner, R.; Stürzenbecher, R.; Zeiml, M. 2009b. Computational mechanics of materials and structures, Engineering Structures 31(6): 1288-1297. doi:10.1016/j.engstruct.2009.01.005

Melcher, J.; Kala, Z.; Holický, M.; Fajkus, M.; Rozlívka, L. 2004. Design characteristics of structural steels based on statistical analysis of metallurgical products, Journal of Constructional Steel Research 60: 795-808. doi:10.1016/S0143-974X(03)00144-5

Melcher, J.; Kala, Z.; Karmazínová, M.; Fajkus, M.; Rozlívka, L.; Puklický, L. 2008. Statistical evaluation of material characteristics and their influence on design strength of structural steels of S355, in Proc. of the 5th European Conference on Steel and Composite Structures, Graz (Austria), 809-814.

Mrázik, A.; Sadovský, Z. 1992. Register of statistic information's about yield strength, material strength and tensility, Part 4 - period 1983-1988, ÚSTARCH SAV, Slovakia (in Slovak).

Rozlívka, L.; Dvořáček, P.; Fajkus, M. 1999. Dimension deviations of welded steel beams and their influence on design strength of structural steels, Stavebni obzor [Building Review] 8(2): 38-43 (in Czech).

Strauss, A.; Kala, Z.; Bergmeister, K.; Hoffmann, S.; Novák, D. 2006. Technologische Eigenschaften von Stählen im europäischen Vergleich, Stahlbau 75, Januar 2006, Heft 1.

Strauss, A.; Frangopol, D. M.; Kim, S. 2008. Use of monitoring extreme data for the performance prediction of structures: bayesian updating, Engineering Structures 30(12, December): 3654-3666. 
Szalai, J. 2003. Overall sensitivity analysis of hot-rolled beamcolumns, int. colloquium, in Proc. of Int. Conference on Metal Structures, Miskolc (Hungary), April 2003. Millpress Science Publishers, Rotterdam, 177-182, 3-5.
Szalai, J.; Papp, F. 2009. On the probabilistic evaluation of the stability resistance of steel columns and beams, Journal of Constructional Steel Research 65(3, March): 569-577.

\section{STATYBINIO PLIENO MECHANINIŲ IR GEOMETRINIŲ CHARAKTERISTIKŲ NUSTATYMAS TAIKANT METALURGIJOS PRODUKTU STATISTINĘ ANALIZE}

\section{Z. Kala, J. Melcher, L. Puklický}

\section{S a n tra k a}

Straipsnyje pateikti Čekijos plienų mechaninių ir geometrinių charakteristikų eksperimentinių tyrimų rezultatai. Atlikti S355 klasės plieno plokštės takumo stiprio matavimai. Nustatytos reikšmės naudojamos ašiniam stipriui apskaičiuoti, o gauti rezultatai palyginti su standartinèmis (nominaliosiomis) vertėmis. Plieno plokščiu ir karštai valcuotų profilių tempiamojo stiprio matavimo rezultatams įvertinti pasitelkta statistinè informacija. Ivertintas dalinio patikimumo koeficiento $\gamma_{\mathrm{M} 0}$ adekvatumas.

Reikšminiai žodžiai: medžiaga, plienas, takumo stipris, patikimumas, konstrukcija, projektavimas, atsitiktinis dydis.

Zdeněk KALA. Professor, PhD Dept of Structural Mechanics, Brno University of Technology, Faculty of Civil Engineering. Author and co-author of 1 book, 3 textbooks and more than 180 scientific papers (120 published abroad), Member of Czech Society for Mechanics. Research interests: stability problems of steel structures, elastic-plastic analysis and optimisation of structures, including material and geometrical nonlinearities, numerical methods in structural mechanics, reliability methods.

Jindřich MELCHER. Professor, DSc Dept of Metal and Timber Structures, Brno University of Technology, Faculty of Civil Engineering. He is author and co-author of more than 170 scientific and special papers, lecture notes and textbooks (80 published abroad), Chartered Engineer, Active member in cooperation concerning the unified European documents within the framework of professional commissions of the CEN, IABSE member, Member of the Engineering Academy of Czech Republic. Research interests: stability problems, lateral buckling of beams and calculation of torsion stress were directly taken over into the text of the national standards ČSN and STN for design of steel structures, reliability analysis of steel structures, experimental research. European prize of the ECCS 2001 (European Convention for Constructional Steelwork) for realized structures (head of a design team).

Libor PUKLICKÝ. PhD student. Dept of Structural Mechanics, Brno University of Technology, Faculty of Civil Engineering. Author and co-author of more than 20 scientific papers. Research interests: elastic-plastic analysis and optimisation of structures, including material and geometrical non-linearities, numerical methods in structural mechanics, reliability methods. 